\title{
THE FLIPPED LEARNING MODEL IN ONLINE EDUCATION FOR SECONDARY TEACHERS
}

\author{
Carmen Romero-García ${ }^{1}$, Olga Buzón-García ${ }^{2}$ (iD) Javier Touron ${ }^{1}$ (iD \\ ${ }^{1}$ Universidad Internacional de la Rioja (Spain) \\ ${ }^{2}$ Universidad de Sevilla (Spain) \\ mariadelcarmen.romero@unir.net,.buzon@us.es,javier.touron@unir.net
}

Received April 2018

Accepted June 2018

\section{Abstract}

The online-based model known as "flipped learning" raises new challenges that are different from those of face-to-face teaching. The flipped learning model enhances the active and autonomous learning of students, changes the relationships between them and with the teacher, and encourages innovation within the learning process. The following paper presents a descriptive, poll-based study after having implemented the model in the Curricular design course offered in two different departments, Mathematics and Technology and Computer Science, as part of the Master's Degree program in Secondary Education Teacher Training, taught online by the International University of La Rioja (UNIR). For this purpose, we have designed a learning model with a series of stages based on the events proposed by Gagné for the design of a teaching unit. In order to analyze the impact that the model has on student performance, the final grades obtained by the students are collected after individually designing a didactic unit, as required to demonstrate their learning, analyzing the difference between the control group and those participating in the designing experience. The results revolve around several axes, such as student satisfaction, the training they received, the perceived usefulness of the training received, the evaluation of the entire training process as it was carried out, and the performance achieved. This model ensures that the student is satisfied with and finds the usefulness of the training received, attains better academic performance and fosters very positive attitudes among the students as a whole.

Keywords - Virtual classrooms, Online courses, Teaching models, Educational innovation.

\section{To cite this article:}

Romero-García, C., Buzón-García, O., \& Touron, J. (2018). The flipped learning model in online education for secondary teachers. Journal of Technology and Science Education, 9(2), 109-121. https://doi.org/10.3926/jotse.435 


\section{Introduction}

In traditional systems of education, teachers present the contents during the class session and are responsible for transmitting the knowledge. After the presentation of the contents and outside the classroom, the students perform tasks or activities to strengthen the teacher's explanations and promote the assimilation of the contents transmitted during the class session (Tourón, Santiago \& Díez, 2014). In this way, students tackle problem-solving on their own, without the help of a teacher to answer any questions that might arise, which would allow the students to continue with the task at hand. When this occurs on a continuous basis, the students become blocked and frustrated, which prevents the proper assimilation of the contents and the acquisition of the corresponding skills and abilities (Goodwin \& Miller, 2013).

The changes that are taking place in society are leading to a situation in which part of the knowledge and even the skills acquired by students may become outdated in a short period of time. The teaching staff cannot ignore these changes and continue to teach in the same way. In today's society, learning, while not neglecting the dimension of knowledge acquisition, must also consist of knowing how to access information, assimilate concepts, apply them to problem solving and ultimately learn to make decisions about one's own work. To meet this need, it is necessary to change the role of the teacher from that of a transmitter of knowledge to a guide for student learning, teaching them to learn for themselves. In short, the shift is from a model focused on the teaching staff to a model in which the student takes an active role in the learning process, learning to learn while acquiring abilities and skills, and at the same time, truly assimilating concepts (Prensky, 2015).

In a model of personalized learning, the students become the main protagonists of the learning process, in which the role of the teacher is more important than ever, as he/she must guide the students in their learning, showing them the resources and strategies for overcoming obstacles (González \& García, 2012). Master classes can be an effective way of transmitting knowledge, but they do not account for the diversity of learning styles in the classroom, and it is common for some students to have problems with following the teacher's explanations, due to a lack of prior knowledge needed to understand the concepts being presented. On the other hand, for other students, the pace of the class can seem slow and repetitive.

The flipped learning model is a student-focused teaching and learning model that was applied at Woodland Park High School in Colorado by two chemistry teachers, Jonathan Bergmann and Aaron Sams, who are considered to be pioneers of this model. They started recording their classes to make them available to those students who could not attend, so that they could follow them. Their classes gradually spread, and their model was considered to be a great innovation. The good results obtained with this model incited other teachers to implement it in their classrooms (Bergman \& Sams, 2014).

\section{The Flipped Learning Model}

The flipped or inverse learning model is:

...a pedagogical approach in which the direct instruction is shifted from the group learning space to the individual learning space. As a result, the group learning space is transformed into a dynamic, interactive learning environment in which the teacher guides the students while they apply the concepts and get creatively involved in the subject (Flipped Learning Network, 2014: page 1).

Teachers who want to delve deeper into this model must incorporate into their teaching practice the so-called four pillars of flipped learning: a flexible environment, a culture of learning, intentional content and a professional facilitator (Sams, Bergmann, Daniels, Bennett, Marshall \& Arfstrom, 2014). A culture of learning refers to the fact that the investment in the class implies that the student must actively take responsibility for his or her own learning, under the guidance and direction of the teacher, in order to achieve significant learning. The flexible environment is defined according to indicators that refer to the 
different learning styles that are considered by the model and to the fact that the classroom can be configured in different ways, depending on the activities to be carried out, i.e., individual or collaborative tasks. The teacher as a guide is flexible in relation to their expectations in terms of evaluating the achievements of each student and the learning times. The intentional, directed content refers to a process of reflection by the teacher in selecting the relevant contents and designing and scheduling activities. The teacher must use active learning methods and strategies that are focused on the students, which permit achieving the previously designed objectives, addressing the needs and interests of the context in which the instruction takes place. The final pillar, professional educators, emphasizes the importance for the teaching staff to have a reflective, self-critical attitude with regard to their teaching practice, aimed at a continuous training process which involves communication and collaboration with other teachers to exchange experiences and constructive criticism. With regard to the students, the teacher must conduct formative assessments that make it possible to detect difficulties in the learning process (Flipped Learning Network, 2014; Hamdan, McKnight, McKnight \& Arfstrom, 2013).

In accordance with the four pillars described, in the flipped learning model, the transmission of concepts occurs before the class, through the use of technological resources (generally videos) designed and created by the teacher. While viewing the videos, students work on the lower learning levels according to Bloom's Taxonomy, performing actions related to lower order cognitive levels, such as understanding and remembering. Students can view the videos as many times as necessary. In addition, the videos are usually supplemented with questions students must answer, which makes them a study material. This makes it possible to have more class time for students to participate in activities and put into practice what they learned, with guidance from the teacher, working on higher order cognitive skills, such as application, analysis, evaluation and creation (Romero-García \& Buzón-García, 2017). The teacher introduces active methodologies in the classroom, involving the students in their learning process, requiring them to interact with their peers, making decisions and solving problems, and ultimately improving the learning process, which becomes significant (Touron, Santiago \& Díez, 2014; Bergman \& Sams, 2015). This gives the teacher more time to customize the teaching and address any questions and obstacles their students might have in an individualized manner (Straw, Quinlan, Harland \& Walker, 2015).

The implementation of the flipped model requires digital tools that offer teachers the ability to present the contents outside the classroom, for example, through videos recorded by the teacher or selected from any of the various sources available. Some of the tools used to record videos are: presentations (PowerPoint) with sound, Explain Everything, Videoscribe and Powtoon. In addition, to detect the students' previous knowledge, tools such as EDpuzzle and Playposit are used. They make it possible to enrich the videos with questions and allow the teacher to see the answers to the questions before the class starts (Chica, 2016). This model can be applied in the classroom with materials found on the Internet, as long as they are adapted to their learning objectives and have sufficient quality (Díez, 2017).

Cooperative learning is a methodology widely used in class when implementing this model of teaching. Students work in small groups to achieve a common goal that requires the effort and individual involvement of all members of the group (Pujolas, 2008). Cooperative learning allows students to develop skills in relation to the rest of their peers, such as flexibility, autonomy and self-esteem, a positive attitude toward learning and better academic performance (Prince, 2004).

There are numerous articles that have been published by secondary and university instructors on the efficiency of the model. In general, all studies highlight greater student involvement and an improvement in their attitudes in the learning process, greater interaction with the teaching staff and a significant increase in academic performance. Greater satisfaction with the teaching-learning process has also been highlighted on behalf of students and teachers alike following the implementation of this model (Berret, 2012; Calvillo, 2014; Carrizosa, 2014; Chung, 2014; Esperanza, 2016; Johnson \& Renner, 2012; Marcey \& Brint, 2011; Papadopoulos \& Román, 2010; Toto \& Nguyen, 2009; Warter-Perez \& Dong, 2012). 
The implementation of the European Convergence process in Spanish universities has enabled the implementation of models of teaching and learning that are more responsive to the training needs demanded by today's society, and has led to changes in teaching methodologies (García-Sanz \& Maquillón, 2011; Zabalza, 2012), in favor of models that permit generic competence training for students (Palomares, 2011). University teaching staffs must guide students in accessing contents and in related activities through an autonomous and supervised learning model that makes it possible to construct and generate knowledge (Herrera \& Enrique, 2008) and promotes the maximum development of their capabilities and professional skills (Pegalajar, 2016).

On the other hand, the introduction of this model in secondary education classrooms requires future teachers to experience the advantages that the learning presents, becoming the true protagonist of the learning process, which is always guided and supported by the teacher. The usefulness of this model in the classroom education of students in the Master's Degree program in Teacher Training has already been judged positively in face-to-face environments. The implementation of this model has resulted in students being more motivated and obtaining greater learning achievements and deeper learning (Martín-Rodríguez \& Santiago-Campión, 2016).

Online training presents characteristics that differentiate it from classroom-based learning, promotes autonomous learning, permits group learning processes to be developed, adapts to different modes of learning and changes the way in which students interact with each other and with the teacher. On the other hand, it opens the door to innovation and a change in learning processes in favor of more constructivist models and methodologies, but it is more difficult to motivate students and encourage their participation in the learning process, as in many cases the virtual classrooms reproduce or imitate traditional instruction (Pallof \& Pratt, 2003; Area \& Adell, 2009; Area, 2009).

This work presents the implementation of the flipped learning model in a teacher training course at the master's level, aimed at training future teachers in the competences of the field of curricular design. The intent is for them to learn what the model consists of by experiencing it as students.

\section{Methodology}

The purpose of this study has been to analyze student satisfaction after the implementation of the flipped learning model in online learning, as well as to study whether there is an improvement in the performance of these students.

This is done using a quasi-experimental design with a non-equivalent control group; in the experimental group, the flipped learning model is applied, while in the control group, a traditional methodology based on master classes is applied.

In the control group, the teacher has explained the theoretical contents on how to create a didactic unit using a PowerPoint presentation in which each theoretical aspect is illustrated with an example. At no time did the students perform activities in class to practice what they have learned.

This experience takes place in a part of the course on curriculum design in two different specializations of the University Master's program for Secondary Education Teacher Training. This is an online Master's program, and so the experience was implemented in a virtual classroom. This allows us to know the impact of this model on the academic results of the students and their perception of the impact on their learning, motivation and the usefulness it has for them as future teachers.

\subsection{Participants}

Participating in the study is a total of 173 students enrolled in the Curriculum Design course in the Master's Degree in Secondary Education Teacher Training at the International University of La Rioja (UNIR) during the 2016-2017 academic year. 
The experimental group is formed by 93 subjects, including 68 students from the Mathematics specialty and 25 from the Information Technology specialty, while the control group is made up of 80 students, of whom 62 are from Mathematics and 18 from Information Technology.

With regard to the profile of the sample, the average age of the subjects is 34.84 years, with a bracket ranging from 22 to 50 years. In terms of gender, $52.7 \%$ are women and $47.3 \%$ are men, all of whom have earned a degree or are graduates with less than one year of teaching experience.

\subsection{Instrument}

An ad hoc instrument was designed using Google Forms, which was shared with the students through the teacher-student communication forum on the learning platform they normally use. Their participation was voluntary and anonymous.

The questionnaire consisted of four dimensions, aimed at determining:

a) The satisfaction of the students with the training received, presenting them with ten items, each with five Likert-scale response options (1: Very low, 2: Low, 3: Medium, 4: High, 5: Very high).

b) The perception of the students as to the usefulness of the training received, consisting of twelve items with four answer choices (0: Not at all, 1: Little, 2: Sufficient, 3: A lot).

c) The assessment of the learning process and resources offered for the learning of the subject in the online environment. In this case, a 10 -item semantic differential is presented with values ranging from 1 to 7.

d) The projection and implementation of this model in other subjects, where the students are asked to respond to two items: one with five Likert-scale response options (1: Not at all, 2: Little, 3: Sufficient, 4: A lot; 5: Totally) and another with a dichotomous response (Yes or No).

After the analysis of reliability of the instrument through optimal scaling (CATPCA), we obtained the following Cronbach's alpha values for each dimension: satisfaction 0.97, usefulness 0.97 and evaluation 0.97; we can thus consider that the instrument has an adequate level of reliability (global scale: 0.98 ).

\subsection{Procedure: Conducting the Experience}

The flipped learning model has been implemented in the Curricular Design course in the specialties of Mathematics and Information Technology, in a virtual classroom to promote active learning and the acquisition of skills by incorporating digital tools. Over the course of five sessions, the students have designed a didactic unit synchronously in the virtual classroom. Prior to these sessions, an initial activity is performed in both the control and experimental groups to determine the starting level of the students. The students in the Mathematics specialty have developed a didactic unit (DU) for the topic "Equations," targeting the academic studies for the 3rd year of Compulsory Secondary Education (ESO). Those in the Information Technology specialty did this for the topic "Publication of contents in ICT" for the 4th year of ESO. Both were meant to be taught in a secondary school in the Community of Madrid.

The overall objective of the proposal was for the students to learn how to prepare a teaching unit that fits the criteria proposed in the course syllabus for the subject that was previously taught. In addition, the following specific objectives were established:

- To perform the different sections that comprise a didactic unit, based on current legislation.

- To specify the elements of the curriculum for the preparation of each of the sections of a DU.

- These sections are related to one another.

- To be acquainted with the flipped learning model.

- To acquire collaborative working skills in an online environment. 


\begin{tabular}{|c|c|}
\hline Objectives & \multirow{2}{*}{ Sections of the DU } \\
\hline Session 1 & \\
\hline $\begin{array}{l}\text { Before the session: } \\
\text { - Identify the sections of a didactic unit } \\
\text { - Explain the relationship between the sections of the didactic unit } \\
\text { During the session: } \\
\text { - Specify the elements of the curriculum for the preparation of each of the } \\
\text { - sections of a DU } \\
\text { - Desphasize the importance of the didactic unit (DU) to be implemented } \\
\text { - Select the appropriate content to achieve the objectives } \\
\text { - Associate each learning objective with the standards that make it possible to } \\
\text { - evaluate its achievement }\end{array}$ & $\begin{array}{l}\text { - Introduction } \\
\text { - } \text { Obojtext and recipients } \\
\text { - Competences and content } \\
\text { - Assessment criteria } \\
\text { - Measurable learning } \\
\text { standards }\end{array}$ \\
\hline \multicolumn{2}{|l|}{ Session 2} \\
\hline $\begin{array}{l}\text { Before the session: } \\
\text { - Recognize teaching methodologies that allow for significant learning of } \\
\text { mathematics } \\
\text { - Identify different types of resources } \\
\text { During the session: } \\
\text { Design activities that permit work to be done on the selected contents and } \\
\text { contribute to the achievement of the proposed objectives and key } \\
\text { competences } \\
\text { - Select the most appropriate resources to carry out the proposed activities }\end{array}$ & $\begin{array}{ll}\text { - } & \text { Methodology } \\
\text { - } & \text { Activities } \\
\text { - } & \text { Scheduling and resources }\end{array}$ \\
\hline \multicolumn{2}{|l|}{ Session 3} \\
\hline $\begin{array}{l}\text { Before the session: } \\
\text { - Identify the steps to take to develop problem-based learning (PBL) } \\
\text { During the session: } \\
\text { - Design a contextualized problem in which the real-life application of the } \\
\text { selected content can be seen: establish the objectives and competences } \\
\text { - Determine the organization of the classroom activity }\end{array}$ & - Design of PBL \\
\hline \multicolumn{2}{|l|}{ Session 4} \\
\hline $\begin{array}{l}\text { Before the session: } \\
\text { - Identify different types of assessment } \\
\text { - Classify assessment instruments according to the type of assessment } \\
\text { - Identify the elements that form part of a rubric and their relationship to the } \\
\text { elements of the curriculum } \\
\text { During the session: } \\
\text { - Select assessment instruments for each of the proposed activities } \\
\text { - Determine the indicators for each assessment instrument } \\
\text { - Determine the percentage of each instrument in the final grade } \\
\text { - Design a rubric to evaluate the PBL designed in the previous session }\end{array}$ & $\begin{array}{l}\text { - Assessment: instruments } \\
\text { and grade \% } \\
\text { - Rubric design }\end{array}$ \\
\hline \multicolumn{2}{|l|}{ Session 5} \\
\hline $\begin{array}{l}\text { During the session: } \\
\text { - Present the DU developed } \\
\text { - Co-evaluate the DU based on the rubric created by the teacher } \\
\text { - Co-evaluate the presentation based on the rubric created by the teacher } \\
\text { - Compare the scores for the DU and presentation with those of the teacher } \\
\text { member based on the rubric created by the teacher }\end{array}$ & $\begin{array}{l}\text { - Presentation of the } \\
\text { didactic units } \\
\text { Co-evaluation and peer- } \\
\text { assessment of the DU } \\
\text { and presentation } \\
\text { - Self-evaluation of the } \\
\text { work performed }\end{array}$ \\
\hline
\end{tabular}

Table 1. Objectives and tasks performed for the design of a didactic unit 


\begin{tabular}{|c|c|c|c|}
\hline Time frame & $\begin{array}{l}\text { Phase in the } \\
\text { Gagné model }\end{array}$ & Methodology & Resources \\
\hline \multirow{4}{*}{$\begin{array}{l}\text { Before the } \\
\text { session }\end{array}$} & Get the attention & \multirow{3}{*}{$\begin{array}{l}\text { Before class, through the study of an explanatory } \\
\text { video of the activity enriched with questions in } \\
\text { EDpuzzle for sessions } 1,2 \text { and } 3 \text {, and a document for } \\
\text { sessions } 4 \text { and } 5 \text {. The aim of the questions is to allow } \\
\text { the teacher to determine before the virtual class } \\
\text { whether the students have a clear understanding of } \\
\text { the theoretical concepts needed to address the } \\
\text { corresponding session. }\end{array}$} & \multirow{3}{*}{$\begin{array}{l}\text { Video enriched with } \\
\text { questions in EDpuzzle. } \\
\text { DU assessment } \\
\text { document. } \\
\text { Document to prepare for } \\
\text { the DU presentation. }\end{array}$} \\
\hline & $\begin{array}{l}\text { Inform about the } \\
\text { objectives }\end{array}$ & & \\
\hline & $\begin{array}{l}\text { Present the } \\
\text { contents }\end{array}$ & & \\
\hline & $\begin{array}{l}\text { Know the } \\
\text { previous ideas }\end{array}$ & $\begin{array}{l}\text { The teacher goes over the answers to the questions } \\
\text { asked in the video to check the previous ideas that the } \\
\text { students bring to the session. }\end{array}$ & $\begin{array}{l}\text { The EDpurzle tool makes } \\
\text { it possible to see the } \\
\text { times the student has } \\
\text { seen the video and the } \\
\text { answers to the questions } \\
\text { included in it. }\end{array}$ \\
\hline \multirow[b]{2}{*}{$\begin{array}{l}\text { During the } \\
\text { session }\end{array}$} & $\begin{array}{l}\text { Guide the } \\
\text { learning }\end{array}$ & $\begin{array}{l}\text { The class begins with a short debate on questions } \\
\text { raised in the video to facilitate understanding ( } 20-30 \\
\text { minutes). The teacher will ask questions and following } \\
\text { the responses, the student appointed secretary of the } \\
\text { session will write the main conclusions on the note } \\
\text { pad. The document will be filed as a record of the } \\
\text { session. }\end{array}$ & $\begin{array}{l}\text { Document to guide the } \\
\text { debate, with a series of } \\
\text { questions based on the } \\
\text { responses by the students } \\
\text { to the questions in the } \\
\text { video. }\end{array}$ \\
\hline & $\begin{array}{l}\text { Promote } \\
\text { performance and } \\
\text { demonstrate } \\
\text { what they have } \\
\text { learned }\end{array}$ & $\begin{array}{l}5 \text { minutes are dedicated to explaining the activity and } \\
\text { the work groups are set up (4-6 students). The } \\
\text { students are assigned the following roles within the } \\
\text { group: } \\
\text { Secretary: responsible for writing on the notepad. } \\
\text { Moderator: summarizes the information from the } \\
\text { forum for recording on the notepad. } \\
\text { Person responsible for monitoring the time. } \\
\text { Responsible for searching for information. } \\
\text { Spokesperson: communicates with the teacher and } \\
\text { responsible for communicating the final results. } \\
\text { They have } 1 \text { hour and } 30 \text { minutes to complete the } \\
\text { activity. }\end{array}$ & $\begin{array}{l}\text { The students have a chat } \\
\text { program they can use to } \\
\text { communicate and a } \\
\text { notepad to record the } \\
\text { results of the work done } \\
\text { during the session. They } \\
\text { have the option to } \\
\text { connect the microphone } \\
\text { to be able to talk. }\end{array}$ \\
\hline $\begin{array}{l}\text { During the } \\
\text { session }\end{array}$ & \multirow{3}{*}{$\begin{array}{l}\text { Provide feedback } \\
\text { and assess } \\
\text { performance }\end{array}$} & $\begin{array}{l}\text { During the activity, the teacher will move among the } \\
\text { groups to give feedback on the work they are doing. }\end{array}$ & \multirow{3}{*}{$\begin{array}{l}\text { Questionnaire developed } \\
\text { with the Socrative tool. } \\
\text { Rubric for the evaluation } \\
\text { of the DU and } \\
\text { presentation. }\end{array}$} \\
\hline $\begin{array}{l}\text { After the } \\
\text { session }\end{array}$ & & $\begin{array}{l}\text { At the end of each session, the teacher files the } \\
\text { notepad from each group with the final result of the } \\
\text { session. The document with the corresponding } \\
\text { feedback (teacher's corrections or comments) is sent } \\
\text { to the students via the forum. The students must take } \\
\text { into account these corrections to guide the next } \\
\text { session. }\end{array}$ & \\
\hline $\begin{array}{l}\text { During the } \\
\text { session }\end{array}$ & & $\begin{array}{l}\text { In the last session, the spokesperson of each group } \\
\text { presents the work carried out and it is evaluated by the } \\
\text { teacher and students based on a rubric which is made } \\
\text { available to them during the first session. Finally, a } \\
\text { self-assessment questionnaire is completed. }\end{array}$ & \\
\hline
\end{tabular}

Table 2. Phases in the design of the instruction implemented in a virtual classroom. Methodology and resources for each phase (based on Buzón-García \& Romero-García, 2017)

The objectives for each of the sessions designed according to this model have been established on the basis of Bloom's revised taxonomy (Anderson, Krathwohl, Airasian, Cruikshank, Mayer, Pintrich et al., 2001). When establishing the objectives, a differentiation has been made between those related to the acquisition of knowledge and those related to putting what has been learned into practice. Table 1 presents the objectives and sections of the DU that the students had to develop in each of the sessions. 
The sessions have been designed incorporating the events proposed by Gagné and Dick (1983). Three time frames are considered for each session: before the session, during the session and after the session. The time when each of the events is carried out, the way in which the work is performed and the resources used are shown in Table 2.

\section{Results}

In order to check whether the sample (experimental and control group) is homogeneous in terms of the levels of performance before the beginning of the experiment, a comparative analysis of the learning outcomes was conducted for the activity previously completed. The Kolmogorov-Smirnov test is applied to check whether the scores have a normal distribution, obtaining as statistical values of the test 0.202 (control group) and 0.197 (experimental group), corresponding to a value of $p=0.000$ in both groups. This statistic tells us that the variable "grades from the previous activity" does not have a normal distribution in either group, and as a result, the data must be analyzed using non-parametric statistics. The Mann-Whitney $U$ test is thus applied, finding that $z=-0.568$, corresponding to a significance of $p=0.401$, which leads us to state that there are no statistically significant differences between the groups in terms of the previous grade.

To analyze the impact of the model on student performance, the final grades earned by the students after they completed the individual design of the assigned educational unit as a product of their learning were examined, analyzing the difference between the control group and those participating in the experience presented here. A Student's $t$ test (Table 3) is applied to compare the mean scores obtained on the didactic units in both groups. The students in the control group have obtained a mean score of 7.6, while those in the experimental group had a mean score of 9.3. The differences between the mean scores is significant $(t=-12.039, p=0.000)$ with a difference of 1.82 in favor of the experimental group.

Finally, Cohen's $D$ test was applied to find out the strength and size of the effect of said change, obtaining a score of $1.66(r=0.64)$, which indicates that $94.52 \%$ of the experimental group scored above the mean of the control group, with a $87.11 \%$ probability that a randomly chosen member of the experimental group would have a higher score than a randomly selected member of the control group.

Based on the responses obtained from the questionnaire and using the SPSS program (v.22), with regard to the degree of satisfaction with the training received (Figure 1), the students indicate that they have an overall level of satisfaction of 3.92, which could be considered high, since the maximum possible value is 5. If we analyze the aspects of this dimension in greater detail, the students emphasize, first of all, the relationship established with the faculty (4.29), followed by the explanations by the teaching staff and the documentation offered for studying the course (both with 4.09), what they learned in the DUs (4.06) and the evaluation and contents delivered (both with 4.05), as well as the resources used (4.04).

With regard to the training received (Figure 2), the students indicate that the most useful aspect has been learning how to correctly structure a DU (2.47), the importance of learning standards (2.45), as well as matching competences to the rest of the elements of a DU (2.37). In short, they state that the training received has enabled them to learn how to design a DU (2.27).

In terms of the third dimension in which the intent was to find out the opinion of the students with regard to the learning process and the resources offered in both courses (Figure 3), most of the items were given scores greater than 5 (on a scale of 1 to 7). In this sense, the students feel that the learning process carried out is essentially useful (5.8), complete (5.52), productive (5.49) and entertaining (5.35).

Finally, with regard to the students' opinion on the application and implementation of this model in other subjects (Figure 4), we can consider the experience to have been very positive. The results indicate that the students have met their expectations in $69 \%$ of the cases (a lot, $44 \%$ and totally, $25 \%$ ), and $81 \%$ would recommend this training to other students (Figure 5). 


\begin{tabular}{|l|r|r|r|r|r|}
\hline Group & $n$ & \multicolumn{1}{|c|}{ Mean } & \multicolumn{1}{c|}{ SD } & \multicolumn{1}{c|}{ Student's $t$} & \multicolumn{1}{c|}{$p$} \\
\hline Control & 73 & 7.472 & 1.020 & -12.039 & 0.000 \\
\hline Experimental & 93 & 9.301 & 0.924 & & \\
\hline
\end{tabular}

Table 3. Student's t test in the control and experimental groups

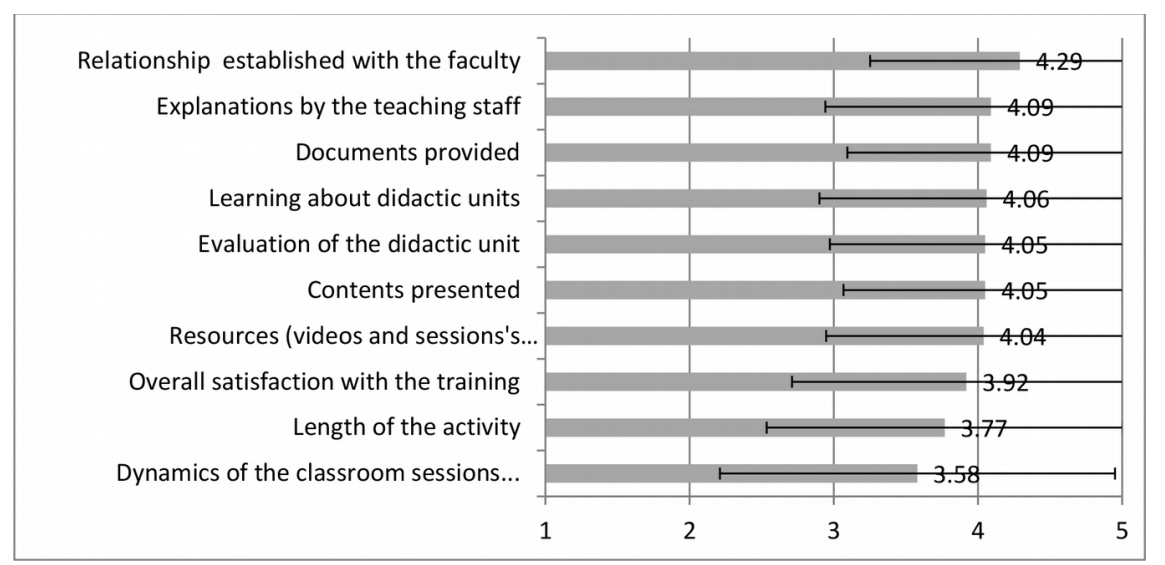

Figure 1. Student satisfaction with the training received (scale of 1 to 5)

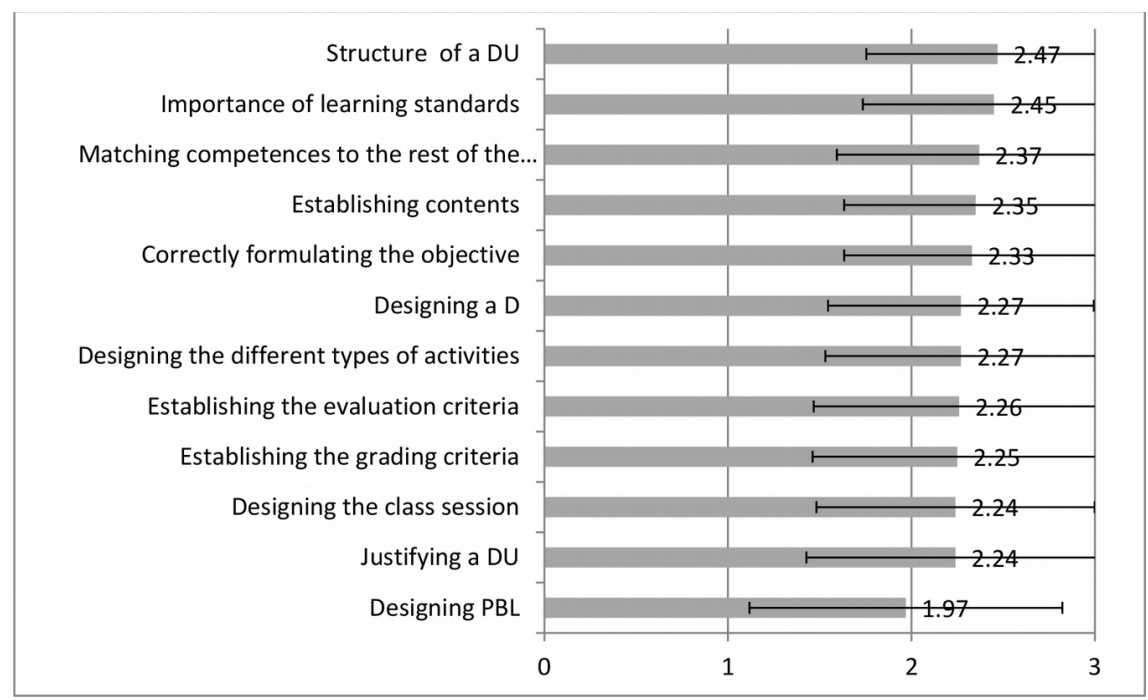

Figure 2. Usefulness of the training received (scale of 0 to 3)

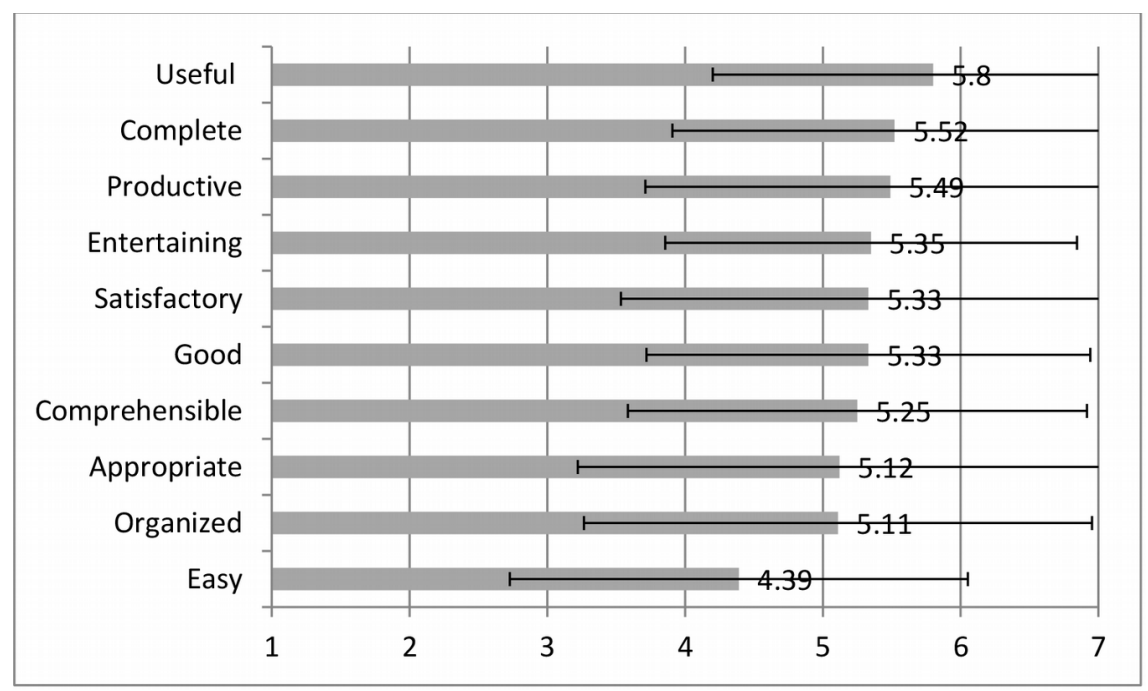

Figure 3. Evaluation of the learning process (scale of 1 to 7 ) 


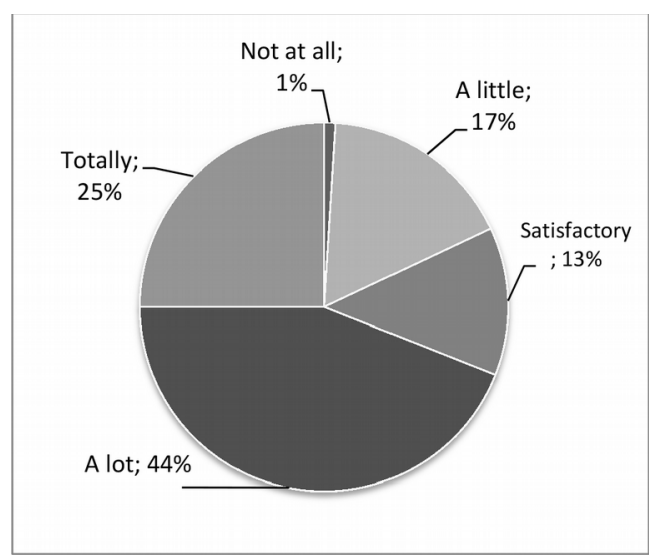

Figure 4. The training received has met expectations

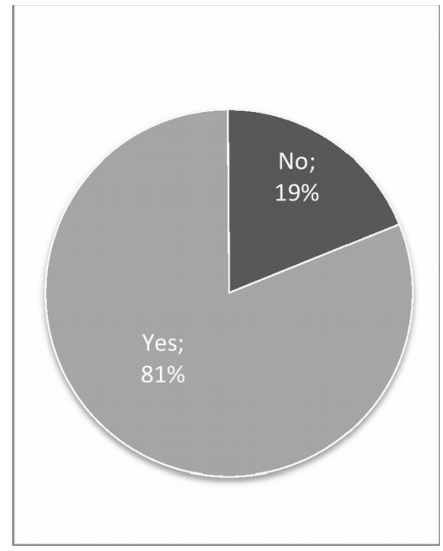

Figure 5. Recommends the training received

\section{Discussion}

Following the implementation of the flipped learning model in online learning, the results in terms of student satisfaction have been very positive. For students, the methodology used in this model is useful, complete, productive and entertaining, so most of them would repeat this experience. These results agree with the contributions made by Yoshida (2016), in which the students assessed the learning according to the flipped classroom model to be useful, stating that it improves the comprehension of the contents and makes better use of the classroom sessions, which results in better motivation and greater interest in their learning (Martín-Rodríguez \& Santiago-Campión, 2016; Martín-Rodríguez \& Tourón, 2017).

With regard to the results on academic performance, the students who have participated in the experience earn better grades than the control group, which allows us to conclude that they improve their performance and the learning process in these subjects. In this sense, these results would be supported by those presented by other authors who have described the usefulness of the model in terms of better grades earned by the students (Goodwin \& Miller, 2013). The studies conducted by Chipps (2013) indicate that the group in which the flipped learning model was implemented showed better performance than the control group, with significant differences between the mean grades of the two groups. In general, different studies have shown that the implementation of the model results in greater efficiency of the learning process, which translates into deep, significant learning (Berret, 2012; Handke, 2014; Prieto, Díaz \& Santiago, 2014; Chung, 2014). It is for this reason that it is considered appropriate for future teachers to be acquainted with the model, given the benefits in terms of motivation and academic performance that are achieved with students. In this sense, we concur with other authors, such as Perdomo (2016), that experimentation with the model has allowed students to see for themselves that significant learning occurs, by promoting collaborative classroom work and debate among students to complete tasks in which they are required to apply the concepts they had previously worked on by themselves.

This model also generates changes in student attitudes, fundamentally towards the learning process. In this sense, the results presented coincide with those of Esperanza (2016), in that a very positive effect is observed on student attitudes following the application of said model.

In spite of the heavy work load it represents for the teaching staff, according to Tourón and Santiago (2015) $99 \%$ of teachers who have used this model state that they would repeat the experience. In fact, the teachers who adopt this instructional model in their classrooms do not go back to the traditional teaching systems. The studies by Calvillo (2014) indicate that the application of the flipped learning model is positive for both students and the teacher alike. On the other hand, even though Toto and Nguyen (2009) conclude that the model is effective if implemented in $25 \%$ of the sessions, we believe that to optimize the results obtained in terms of both performance and motivation, it is necessary to increase the number of sessions in which it is implemented, since as Johnson and Renner (2012) indicate, prior preparation of the students is required to adapt to the model and this new form of teaching and learning. 
The results obtained in this research study offer more evidence of a focus that is steadily gaining ground, and thus the implementation of the flipped learning model in an online environment in even greater depth is considered.

\section{Declaration of Conflicting Interests}

The authors declared no potential conflicts of interest with respect to the research, authorship, and/or publication of this article.

\section{Funding}

The authors received no financial support for the research, authorship, and/or publication of this article.

\section{References}

Anderson, L.W. (Ed.), Krathwohl, D.R. (Ed.), Airasian, P.W., Cruikshank, K.A., Mayer, R.E., Pintrich, P.R. et al. (2001). A taxonomy for learning, teaching, and assessing: A revision of Bloom's Taxonomy of Educational Objectives (complete edition). New York: Longman.

Area, M. (2009). La formación y el aprendizaje en entornos virtuales. Potencialidades, debilidades y tendencias. Crítica, 82, 33-36.

Area, M., \& Adell, J. (2009). ELearning: Enseñar y aprender en espacios virtuales. In De Pablos, J. (Coord.), Tecnología Educativa. La formación del profesorado en la era de Internet (391-424). Málaga: Aljibe.

Bergmann, J., \& Sams, A. (2015). Dale la vuelta a tu clase. Lleva tu clase a cada estudiante, en cualquier momento y cualquier lugar. España: Ediciones SM.

Bergmann, J., \& Sams, A. (2014). Dale la vuelta a tu clase. Barcelona: Ediciones SM.

Berrett, D. (2012) How 'flipping' the classroom can improve the traditional lecture. The Chronicle of Higher Education. Available at: http://chronicle.com/article/How-Flipping-the-Classroom/130857/

Buzón-García, O., \& Romero-García, C. (2017). Aplicación del modelo Flipped Classroom en un entorno online para la formación del profesorado de secundaria. In AIDIPE 2017 (Eds.), XVIII Congreso Internacional de Investigación Educativa: Interdisciplinariedad y transferencia, Salamanca, Spain.

Calvillo, A.J. (2014). El modelo Flipped Learning aplicado a la materia de música en el cuarto curso de Educación Secundaria Obligatoria: una investigación-acción para la mejora de la práctica docente y del rendimiento académico del alumnado (Doctoral thesis). Universidad de Valladolid, Spain. Available at: https://www.educacion.gob.es/teseo/mostrarRef.do?ref=1118301

Carrizosa, P.E (2014). Metodología Flipped Learning e Innovacción Docente. 1 Seminario Iberoamericano de Innovación Docente de la Universidad Pablo de Olavide (1-5). Sevilla. Available at:: http://www.upo.es/ocs/index.php/sididoupo/sidiupo/paper/view/184

Chica, D. (2016). Flipped Classroom: herramientas más destacadas para comenzar a invertir (en) tu aula (Message on a blog). Available at: http://www.educacontic.es/ca/blog/flipped-classroom-herramientas-mas-destacadas-paracomenzar-invertir-en-tu-aula-dchicapardo

Chipps, J. (2013). The Effectiveness of Using Online Instructional Videos with Group Problem-Solving to Flip the Calculus Classroom. Available at: http://ichipps.com/docs/thesis.pdf

Chung, K. (2014). Professors 'flip' classrooms, enhance learning. Daily Tar Heel. Available at: http://www.dailytarheel.com/article/2014/01/flipped-classrooms-0108

Díez, A. (2017). Recursos para la clase inversa: consideraciones tecnológicas. Newsletter the Flipped Classroom, 5, 4-5. Available at:

http://clicks.aweber.com/y/ct/?l=ANEID\&m=gzk0 lwWmQABUqU\&b=dMv2XUUNcHG2Yy27zvo0Sg

Esperanza, P. (2016). The power of the flipped classroom: Achieving high academic student performance through multimedia learning (Electronic book). Available at: Apple iBooks Store (iTunes):

$\underline{\text { https://itunes.apple.com/us/book/power-flipped-classroom/id1048431489?mt=11 }}$ 
Flipped Learning Network (2014). The Four Pillars of F-L-I-PTM. Available at:

http://fln.schoolwires.net/cms/lib07/VA01923112/Centricity/Domain/46/FLIP handout FNL Web.pdf

Gagné, R.M., \& Dick, W. (1983). Instructional Psychology. Annual Review of Psychology, 34, 261-195. https://doi.org/10.1146/annurev.ps.34.020183.001401

García-Sanz, M.P., \& Maquillón, J.J. (2011). El futuro de la formación del profesorado universitario. Revista Electrónica Interuniversitaria de Formación del Profesorado, 14(1), 17-26.

González, N., \& García, J.L. (2012). Metodologías participativas para la mejora del aprendizaje en Educación Superior. Un proyecto innovador con estudiantes de la Facultad de Educación. Revista Iberoamericana para la investigación y el desarrollo educativo, 3(5), 80-93.

Goodwin, B., \& Miller, K. (2013). Research says evidence on Flipped Classrooms is still coming in. Technology Rich Learning, 70(6), 78-80. Available at: http://www.ascd.org/publications/educationalleadership/mar13/vol70/num06/Evidence-on-Flipped-Classrooms-Is-Still-Coming-In.aspx

Hamdan, N., McKnight, P., McKnight, K., \& Arfstrom, K. (2013). The flipped learning model: A white paper based on the literature review titled a review of flipped learning. Flipped Learning Network (FLN), Pearson's Center for Educator Effectiveness y George Mason University. Available at: http://flippedlearning.org/wp-content/uploads/2016/07/WhitePaper FlippedLearning.pdf

Handke, J. (2014). Evaluationen und studentische Selbsteinschätzungen. Available at: http://invertedclassroom.wordpress.com/2014/02/13/das-icmm-im-ws-201314/

Herrera, L., \& Enrique, D. (2008). Proyectos de Innovación en tutorías en la Universidad de Granada: Análisis de los instrumentos empleados. Profesorado. Revista de Curriculum y Formación del Profesorado, 12(2), 1-18. Available at: http://www.ugr.es/ recfpro/rev122COL5.pdf

Johnson, L.W., \& Renner, J.D. (2012). Effect of the flipped classroom model on a secondary computer applications course: Student and teacher perceptions, questions, and student achievement (Doctoral dissertation). University of Louisville, Kentucky. Available at: http://theflippedclassroom.files.wordpress.com/2012/04/johnsonrenner-2012.pdf

Marcey, D., \& Brint, M. (2011). Transforming an undergraduate introductory biology course through cinematic lectures and inverted classes: a preliminary assessment of the clic model of the flipped classroom. California Lutheran University, Thousand Oaks, California. Available at: https://nabt.org/files/galleries/Marcey Brint.pdf

Martín-Rodríguez, D., \& Santiago-Campión, R. (2016). Flipped learning en la formación del profesorado de secundaria y bachillerato. Formación para el cambio. Contextos Educativos, 1, 117-134. https://doi.org/10.18172/con.2854

Martín-Rodríguez, D., \& Tourón, J. (2017). El enfoque flipped learning en estudios de magisterio: percepción de los alumnos. RIED. Revista Iberoamericana de Educación a Distancia, 20(2), 187-211. https://doi.org/10.5944/ried.20.2.17704

Palomares, A. (2011). El modelo docente universitario y el uso de nuevas metodologías en la enseñanza, aprendizaje y evaluación. Revista de Educación, 355, 591-604. Available at:

http://www.revistaeducacion.educacion.es/re355_25.html

Pallof, R., \& Pratt, K. (2003). The virtual student. San Francisco: Jossey Bass Wiley.

Papadopoulos, C., \& Román, A.S. (2010). Implementing an Inverted Classroom Model in Engineering Statics. Conference presented in Mechanics Division of the ASEE Annual Conference and Exposition. Louisville, Kentucky.

Pegalajar, M.C. (2016). Percepciones del alumnado de posgrado acerca de la metodología docente y evaluativa. Profesorado. Revista de Currículum y Formación del Profesorado, 20(2), 99-119. Available at: https://recyt.fecyt.es/index.php/profesorado/article/view/52093/31778

Perdomo, W. (2016). Estudio de evidencias de aprendizaje significativo en un aula bajo el modelo flipped classroom. Edutec. Revista Electrónica de Investigación Educativa, 55, 1-17. Available at: http://www.edutec.es/revista/index.php/edutece/article/view/618/Edutec n55 Perdomo 
Prensky, M. (2015). Prologue. In Bergmann, J., \& Sams, A. (Authors), Dale la vuelta a tu clase. Lleva tu clase a cada estudiante, en cualquier momento y cualquier lugar (2nd ed., 5-12). Spain: Ediciones SM.

Prieto, A., Díaz, D., \& Santiago, R. (2014). Metodologías Inductivas: El desafio de enseñar mediante el cuestionamiento y los retos. Barcelona: Digital-text.

Prince, M. (2004). Does Active Learning Work? A Review of the Research. Journal of Engineering Education, 93, 223-232. https://doi.org/10.1002/j.2168-9830.2004.tb00809.x

Pujolàs, P. (2008). Introducció a l'aprenentatge cooperatiu. Vic: Facultat d'Educació. Laboratori de Psicopedagogia. Universitat de Vic. Available at: http://www.iesjosepsuredaiblanes.com/wpcontent/uploads/2014/12/Introduccio aprenentatge cooperatiu.pdf

Romero-García, M.C., \& Buzón-García, O. (2017). Aprendizaje activo en la formación de futuros profesores de matemáticas en un entorno virtual. En XXV Jornadas Universitarias de Tecnología Educativa. Burgos, Spain.

Sams, A., Bergmann, J., Daniels, K., Bennett, B., Marshall, H., \& Arfstrom, K. (2014). Definición de aprendizaje inverso (imagen). Available at: Flipped Learning Network http://flippedlearning.org/wpcontent/uploads/2016/07/PilaresFlip.pdf

Straw, S., Quinlan, O., Harland, J., \& Walker, M. (2015). Flipped learning (research report). London: National Foundation for Educational Research. Available at: https://www.nfer.ac.uk/publications/NESM01/NESM01.pdf

Toto, R., \& Nguyen, H. (2009). Flipping the Work Design in an Industrial Engineering Course. Conference in Frontiers in Education Conference. San Antonio, Texas. https://doi.org/10.1109/FIE.2009.5350529

Tourón, J., \& Santiago, R. (2015). El modelo flipped learning y el desarrollo del talento en la escuela. Revista de Educación, 368, 196-208.

Tourón, J., Santiago, R., \& Díez, A. (2014). The flipped classroom: Cómo convertir la escuela en un espacio de aprendizaje (Electronic book) Digital-Text. Grupo Océano. Available at: Apple iBooks Store (iTunes) https://itunes.apple.com/es/book/the-flipped-classroom/id930102415?mt=11

Warter-Perez, N., \& Dong, J. (2012). Flipping the classroom: How to embed inquiry and design projects into a digital engineering lecture. Conference presented in ASEE PSW Section Conference. California Polytechnic State University, San Luis Obispo. Available at: http://aseepsw2012.calpoly.edu/site media/uploads/proceedings/papers/10B 35 ASEE PSW 2012 Warte r-Perez.pdf

Yoshida, H. (2016). Perceived Usefulness of "Flipped Learning" on instructional design for elementary and secondary education: with focus on pre-service teacher education. International Journal of Information and Education Technology, 6(6), 430-434. https://doi.org/10.7763/IJIET.2016.V6.727

Zabalda, M.A. (2012). El estudio de las "buenas prácticas" docentes en la enseñanza universitaria. Revista de Docencia Universitatia, 10(1), 17-42. Available at: http://red- u.net/redu/index.php/REDU/article/view/363 https://doi.org/10.4995/redu.2012.6120

Published by OmniaScience (www.omniascience.com)

Journal of Technology and Science Education, 2018 (www.jotse.org)

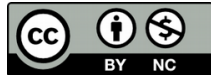

Article's contents are provided on an Attribution-Non Commercial 4.0 Creative commons International License. Readers are allowed to copy, distribute and communicate article's contents, provided the author's and JOTSE journal's names are included. It must not be used for commercial purposes. To see the complete licence contents, please visit https://creativecommons.org/licenses/by-nc/4.0/. 